\title{
Balancing Human Rights and Customs in the Pacific Region: A Pacific Charter of Human Rights?
}

\author{
KELLY HAINES-SUTHERLAND
}

\section{Abstract}

This paper examines whether a regional human rights instrument could be designed for the Pacific that would reconcile human rights with Pacific customs, duties and collective practices. The paper will explore an area of Pacific custom that conflicts with women's rights encapsulated in international human rights treaties: the traditional practices of bride payment and tribal determination of marriage partners. These examples serve to highlight the difficulties inherent in constructing a charter that balances the protection of human rights and customs. The current system of human rights protection in the Pacific will be outlined, and the prospects for success of a regional charter will be examined. Furthermore, the paper discusses the theoretical debate concerning cultural relativism and universalism in international law, and what this debate says about the viability of a Pacific Charter of Human Rights. Finally, other challenges to a charter, minority rights and codifying custom, will be highlighted. The paper concludes that an inventory of customs and human rights common to the Pacific region could form the foundations of a Pacific Charter of Human Rights, but that some difficult areas such as reconciling women's rights with Pacific practices remain unresolved.

\section{Introduction}

The Pacific is one of the last regions of the world without a regional mechanism for the protection of human rights. This paper will examine the viability of a Pacific Charter of Human Rights, and whether such a document would need its own Pacific flavor to cater for local customs and culture. The key challenge 
is creating a document that is not just symbolic, but is representative of the region and its peoples. A representative and effective charter must balance the aims of protecting the human rights of Pacific Islanders while safeguarding their customs, values and practices.

\section{Human Rights}

Human rights are the norms set out in international human rights instruments, which have been devised predominantly by the United Nations. The principal document that stipulates human rights is The Universal Declaration of Human Rights (UDHR), which was adopted by the United Nations General Assembly in 1948. Seven human rights treaties now constitute the international legal framework that governs the protection of human rights.

Human rights are considered by the drafters of international human rights instruments to be universal and inalienable norms and 'inherent in persons by virtue of their humanity'. ${ }^{1}$ Therefore international human rights treaties are perceived as the codification of rights that already exist. ${ }^{2}$ Article 1 of the UDHR encapsulates this idea: 'All human beings are born free and equal in dignity and rights' ${ }^{3}$ However, there is debate as to whether human rights are universal and inalienable, or defined by cultural and social context. This debate is discussed below.

International human rights instruments are largely based upon the concept of the rights of the individual. The human rights movement stems from a liberal tradition of Western political and legal thought, which privileges individual rights over cultural and group rights. ${ }^{4}$ Furthermore, even where cultural and group rights exist in international treaties, they are formulated from an individual perspective. ${ }^{5}$ A Pacific Charter of Human Rights would need to incorporate cultural and group rights, which are fundamental to Pacific societies.

\footnotetext{
1 New Zealand Law Commission, Converging Currents: Custom and Human Rights in the Pacific (2006) 60.

2 Ibid 61

3 United Nations, The Universal Declaration of Human Rights, (1948) <http://www.un.org/en/documents/ udhr/index.shtml $>$ at 26 October 2010.

4 Paul Hunt, 'Reflections on International Human Rights Law and Cultural Rights' in Margaret Wilson and Paul Hunt (eds), Culture, Rights and Cultural Rights: Perspectives from the South Pacific (2000) 25, 25.

5 Ibid 35.
} 


\section{Pacific Customs, Duties and Collective Practices}

Custom is an integral part of Pacific culture. The New Zealand Law Commission defines custom broadly as 'the values, principles and norms that members of a cultural community accept as establishing standards for appropriate conduct, and the practices and processes that give effect to community values' ${ }^{6}$ Jean Zorn contends that practices become custom when they are fairly regularly practised by a large segment of the community. ${ }^{7}$ Customary law is what the people of a particular community consider they are bound to do or not to do. ${ }^{8}$ Examples of Pacific customs that will be discussed in this paper include tribal determination of marriage partners and bride payments.

Customary law was used in pre-colonial Pacific societies as the principal means of governance. Zorn describes how Pacific societies functioned without central authority:

Without state mechanisms...the Pacific nevertheless had functioning legal systems. They had complex sets of unwritten rules governing aspects of social, political and economic behaviour. They had effective methods for ensuring that the rules would be followed and they also had workable procedures for settling disputes. ${ }^{9}$

Customary law is still widely used as a means of governance in the Pacific. Daily life in the small island states of Tokelau and Wallis and Futuna is almost completely governed by customary law. ${ }^{10}$ In order to be relevant to the Pacific context, a Pacific Charter of Human Rights would need to allow for the continuation of Pacific custom, values and practices.

Custom has altered considerably over time to reflect social, economic, political and religious changes in the Pacific. ${ }^{11}$ Colonisation and the introduction of Christianity to the Pacific have had a considerable effect on custom, so that it has diverged from pre-colonial custom. ${ }^{12}$ Many pre-colonial beliefs and values were modified by missionary teachings. ${ }^{13}$ A question for drafters of a Pacific Charter of Human Rights is whether custom that is included in the charter should reflect traditional or modern custom, values and practices.

6 New Zealand Law Commission, above n 1, 47.

7 Jean G. Zorn, 'Custom then and now: the changing Melanesian family' in Anita Jowitt and Tess Newton

Cain (eds), Passage of Change: Law Society and Governance in the Pacific (2003) 95, 101.

8 New Zealand Law Commission, above n 1, 47.

9 Zorn, above n 7, 96.

10 New Zealand Law Commission, above n 1, 41.

11 Ibid 55.

12 Ibid.

13 Ibid 58. 
Collective practices are also an integral part of Pacific society, where the extended family, clan or tribe are central to the peoples' way of life. Konai Helu Thaman describes life in the Pacific as a 'shared way of living of a group of people, which includes their accumulated knowledge and understandings, skills and values' ${ }^{14}$ The focus on the clan above the individual in the Pacific may mean that collective rights may subjugate certain individual rights. The example provided in this research paper is the collective determination of marital partners in Pacific tribes, which conflicts with a woman's right to choose their partner in international human rights law. A Pacific Charter of Human Rights would need to find a way of balancing collective rights and individual rights, so that it reflects the reality of life in the Pacific while protecting fundamental individual rights.

In contrast to the Western liberal conception of individual rights as paramount, the traditional value systems of the Pacific emphasise the duties of the individual to the group. ${ }^{15}$ Andreas Follesdal describes Pacific societies as duty-oriented:

Our cultures, societies and traditions [place] great emphasis on the individual human duties and obligations to respect customary norms, laws and familial and chiefly authority rather than rights. ${ }^{16}$

However, international human rights instruments largely exclude duties. ${ }^{17}$ This conflict between duties and rights must be addressed in preparing a Pacific Charter of Human Rights.

\section{Cultural Relativism vs Universalism}

The conflict between cultural relativism and universalism is central to the debate over whether human rights and customs can be reconciled to create a Pacific Charter of Human Rights. Universalists contend that human rights are absolute and applicable to all societies. ${ }^{18}$ Cultural relativists contend that human rights

14 Konai Helu Thaman, 'Cultural Rights: A personal perspective' in Margaret Wilson and Paul Hunt (eds), Culture, Rights and Cultural Rights: Perspectives from the South Pacific (2000) 1, 1.

15 Guy Powles, 'Duties of individuals: some implications for the Pacific of including "duties" in "human rights" documents' in Victoria University of Wellington (ed), Essays and Documents on Human Rights in the Pacific (1992) 49, 49.

16 Ibid.

17 Andreas Follesdal, Human Rights and Relativism (2003) <http://www.etikk.no/globaljustice/papers/ GJ2003_Follesdal_Human_Rights_and_Relativism.doc> at 26 October 2010.

18 New Zealand Law Commission, above n 1, 70. 
are based on Western liberal values, and do not necessarily apply to all cultures and societies. ${ }^{19}$ The middle ground between these two contrasting positions is that some norms are universal, while others are relative to culture and context. ${ }^{20}$

Universalists dismiss the arguments of cultural relativists as conveniently espoused by those in power. Rosalyn Higgins comments that relativism is a point mostly advanced by states...It is rarely advanced by the oppressed, who are only too anxious to benefit from perceived universal standards' ${ }^{21}$ Universal norms can be supplemented with cultural and group rights and duties, which are important in the Pacific context. The New Zealand Law Commission contends that international law is also being expanded to give greater recognition to custom and group rights. ${ }^{22}$ For example, articles 5 and 34 of the Declaration on the Rights of Indigenous Peoples (2007) recognise the right of indigenous people to maintain their legal systems and customs in accordance with international law. ${ }^{23}$

Cultural relativists assert that human rights should be determined by local cultural values and custom. ${ }^{24}$ Sally Engle Merry contends that human rights are embedded in Western liberal assumptions 'about the nature of the person, the community and the state [and] do not translate easily from one setting to another'. ${ }^{25}$ A more extreme view advocated by cultural relativists is that universal norms are destroying the diversity of Pacific cultures, ${ }^{26}$ are disruptive of customary social structures and subversive of traditional authority. ${ }^{27}$ In their extreme forms, cultural relativism and universalism are seemingly irreconcilable.

However, there are several means by which cultural relativism and universalism can be made more compatible. First, some norms may exist universally, such as the principle of human dignity. ${ }^{28}$ Jennifer Corrin Care suggests that it is possible to develop a core of basic rights that are common to all cultures. ${ }^{29}$ Second, culture and human rights are both changing and dynamic, as Engle Merry highlights:

\footnotetext{
19 Ibid.

20 Henry J. Steiner, Phillip Alston and Ryan Goodman, International Human Rights in Context: Law, Politics, Morals (3rd ed, 2008) 515.

21 Rosalyn Higgins, Problems and Process: International Law and How We Use It (1994) 96.

22 New Zealand Law Commission, above n 1, 43.

23 Ibid.

24 Dejo Olowu, 'The United Nations Human Rights Treaty System and the Challenges of Commitment and Compliance in the South Pacific' (2006) 7 Melbourne Journal of International Law 155, 161.

25 Sally Engle Merry, Human Rights and Gender Violence (2006) 2.

26 New Zealand Law Commission, above n 1, 21.

27 Steiner, Alston, Goodman, above n 20, 475

28 Ibid 519.

29 Jennifer Corrin Care, Conflict between customary law and human rights in the South Pacific (1999) $4<$ www. vanuatu.usp.ac.fj/sol-adobe_documents/usp\%20only/pacfic\%20law/corrin> at 20 August 2009, 16.
} 
Considering cultures as changing and interconnected, and rights as historically created and transnationally redefined by national and local actors, better describes the contemporary situation. It also reveals the impossibility of drawing sharp distinctions between culture and rights or seeing relativism and universalism as diametrically opposed and incompatible positions. ${ }^{30}$

Indeed, human rights norms are broadly phrased and thus can potentially be adapted according to cultural context. ${ }^{31}$ This is manifest in regional charters adopted by other regions, that incorporate universal norms but also reflect cultural diversity. For example, the African Charter on Human and Peoples' Rights $^{32}$ links the concepts of human rights, group rights and the duties of individuals to family and society. ${ }^{33}$ However there are some Pacific customs that appear to fundamentally conflict with human rights, which suggests that there may be a limit to the compatibility of human rights and Pacific custom.

\section{Women's Rights and Pacific Custom}

The conflict between human rights and Pacific customs is illustrated by patriarchal practices that infringe on the rights of women contained in international human rights instruments. In many Pacific communities, women can neither choose their marital partners nor terminate a marriage once contracted. ${ }^{34}$ Instead, the men of a tribe determine who a woman's marital partner will be. Women are chosen as wives based on customary rules governing incest, and on criteria including age, beauty, industriousness and social class. ${ }^{35}$ Bride payments are also a 'uniform and widespread custom' in the Pacific. ${ }^{36}$ Anthropologist Douglas Oliver states that the price paid for a bride is usually for her sexual, domestic and reproductive services. ${ }^{37}$

As a result, Pacific women experience high levels of domestic violence. ${ }^{38}$ Martha Macintyre suggests that in many societies in the South Pacific there is a

\footnotetext{
30 Sally Engle Merry, 'Changing Rights, Changing Culture' in Jane K. Cowan, Marie-Benedicte Dembour and Richard A. Wilson (eds), Culture and Rights: Anthropological Perspectives (2001) 31, 39.

31 New Zealand Law Commission, above n 1, 70.

32 African Charter on Human and Peoples' Rights, opened for signature 27 June 1981, 1520 UNTS 217 (entered into force 21 October 1986).

33 Petra Butler, A Human Rights Charter for the Pacific (2005) Human Rights Research: Victoria Human Rights Programme $2<$ http://www.victoria.ac.nz/nzcpl/HRRJ/vol3/Butler.pdf $>$ at 26 October 2010, 11.

34 New Zealand Law Commission, above $\mathrm{n}$ 1, 4.

35 Douglas L. Oliver, Native Cultures of the Pacific Islands (1989) 63.

36 Kenneth Brown, 'Customary Law in the Pacific: An Endangered Species' (1999) 3 Journal of South Pacific Law 1, 3.

37 Oliver, above n 35, 62.

38 Amnesty International, Pacific Leaders must address high rates of violence against women (2009) <http:// www.amnesty.org.au/news/comments/21494> at 26 October 2010.
} 
belief that husbands gain the right to physically punish their wives by virtue of bride payments. ${ }^{39}$ Margaret Jolly describes the effect of the custom of bride price on women: 'Women are paid in the guise of bride price for their labour, both in the bed and in the garden, they allow their bodies to be battered, to be abused and discarded'. ${ }^{40}$ It must be acknowledged however, that levels of domestic violence vary greatly throughout the Pacific. ${ }^{41}$ In Papua New Guinea many women accept the right of their husbands to beat them, whereas in other countries physical abuse requires the payment of a fine to a wife. ${ }^{42}$

International human rights law requires equality and non-discrimination between men and women. For example, articles 2(f) and 5(a) of the Convention on the Elimination of All Forms of Discrimination Against Women (CEDAW) require states to take all appropriate actions to modify or abolish customs and practices that constitute discrimination or that are based on the idea of inferiority, superiority or on stereotyped roles for women. ${ }^{43}$ Furthermore, international human rights instruments include provisions guaranteeing the rights of women to enter into marriage only by the full and free consent of both parties ${ }^{44}$ and to have the same rights and responsibilities as a man during marriage and in the event of dissolution of the marriage. ${ }^{45}$ These provisions contained in international human rights instruments directly conflict with the customs of bride payments and patriarchal determination of marriage partners in the Pacific.

There is some debate as to whether practices that infringe on women's rights are a product of traditional custom, or custom that has evolved and modified over time. Steven Fischer contends that the subordinate position of women in the Pacific only worsened as a result of colonisation and the widespread introduction of Christianity in the Pacific. ${ }^{46}$ Christianity had a detrimental effect on Pacific women through missionary teachings on the subordinate position

39 Martha Macintyre, 'Hear us, women of Papua New Guinea!: Melanesian women and human rights' in Anne-Marie Hilsdon et al (eds), Human Rights and Gender Politics: Asia-Pacific perspectives (2000) 147, 150.

40 Margaret Jolly, 'Women ikat raet long human raet o no?: women's rights, human rights, and domestic violence in Vanuatu' in Anne-Marie Hilsdon et al (eds), Human Rights and Gender Politics: Asia-Pacific perspectives (2000) 124, 134.

41 Steven Roger Fischer, A History of the Pacific Islands (2002) 277.

42 Macintyre, above n 39, 150.

43 Convention on the Elimination of All Forms of Discrimination Against Women, opened for signature 18 December 1979, 1249 UNTS 13, arts 2(f) and 5(a) (entered into force 3 September 1981).

44 International Covenant on Economic, Social and Cultural Rights, opened for signature 16 December 1966, 993 UNTS 3, art 10(1) (entered into force 3 January 1976); International Covenant on Civil and Political Rights, opened for signature 16 December 1966, 999 UNTS 171, art 23(3) (entered into force 23 March 1976); Convention on the Elimination of All Forms of Discrimination Against Women, opened for signature 18 December 1979, 1249 UNTS 13, art 16(c) (entered into force 3 September 1981).

45 Convention on the Elimination of All Forms of Discrimination Against Women, opened for signature 18 December 1979, 1249 UNTS 13, art 16(c) (entered into force 3 September 1981); International Covenant on Civil and Political Rights, opened for signature 16 December 1966, 999 UNTS 171, art 23(4) (entered into force 23 March 1976);

46 Fischer, above n 41, 276. 
of women, forcing women to adopt men's surnames, ${ }^{47}$ and abolishing separate men's houses, resulting in an increase in domestic violence. ${ }^{48}$ Conversely, some traditional brutal practices against women were abandoned with the introduction of Christianity, ${ }^{49}$ and some churches have assisted women in advocating for equality. ${ }^{50}$ Kenneth Brown asserts that while pre-colonial societies were undeniably patriarchal, colonial administrations played a role in institutionalising and entrenching patriarchy by codifying customs, laws and structures that operated to crystallise discrimination against women. ${ }^{51}$

Conversely, Macintyre contends that discrimination against women in the precolonial era is analogous to the discrimination experienced by Pacific women today. $^{52}$ Macintyre suggests that most customary groups had no tradition of rights for women prior to colonisation; women's lack of capacity was ubiquitous and extended to all forms of law. ${ }^{53}$ In addition, the customary system was based on male domination and traditional dispute resolution was presided over by men. ${ }^{54}$ It is important to note that women's status varied greatly between Pacific nations and societies. There is no doubt that customary practices changed due to colonisation and the introduction of Christianity, however it is debatable whether these changes to the Pacific way of life operated to increase the discrimination, inequality and violence suffered by Pacific women. This debate is central to the question of whether a Pacific Charter of Human Rights should incorporate traditional or modern custom.

Determining whether pre-colonial custom was discriminatory in the treatment of Pacific women has been made difficult by loss of knowledge and by biased recordings. ${ }^{55}$ Loss of traditional knowledge upon colonisation resulted in reliance upon the literary recordings of missionaries, colonists and ethnographers. ${ }^{56}$ The New Zealand Law Commission contends that these people interpreted custom from a Western male perspective, leading to a bias in recordings of Pacific customs. ${ }^{57}$ The Fiji Women's Rights Project states that '[t]radition, culture and custom in the main is defined by men, not women - therefore there is a conflict about whose custom is being applied, especially given that custom is largely

\footnotetext{
47 New Zealand Law Commission, above n 1, 88.

48 Jean G. Zorn, Women,Custom and International Law in the Pacific (Occasional Paper 5, University of the South Pacific, Port Vila 2000) 13.

49 New Zealand Law Commission, above n 1, 88.

50 Keiti Ann Kanongata'a, 'Pacific Women and Theology' (1995) 13 Pacific Journal of Theology 17, 17.

51 Brown, above $\mathrm{n} 36,4$.

52 Macintyre, above n 39, 151.

53 Brown, above n 36, 4.

54 Corrin Care, above n 29, 2.

55 New Zealand Law Commission, above n 1, 87.

56 Ibid.

57 Ibid.
} 
unwritten'.$^{58}$ Indeed men have assumed a central role in recording and codifying custom. ${ }^{59}$ Through Western education, Pacific women have begun to question their traditional obligation of subordination due to this bias in recordings. ${ }^{60}$

The key question is whether custom can be adapted to accommodate equality in status, a right guaranteed by international human rights instruments. Drafters of a Pacific Charter of Human Rights would presumably wish to incorporate provisions guaranteeing equality of rights for women and non-discrimination. The paper has highlighted the changing and dynamic capacity of custom, and its previous adaptation to Christianity and colonisation. The New Zealand Law Commission points out that acknowledgement of women's rights and equality in status in other societies (including Western societies) has only been a recent development. ${ }^{61}$ Thus it seems possible that Pacific custom could change to accommodate modern notions of the equal status and rights of women.

The resistance to equal rights for women, and to other human rights protections, is coming predominantly from those who benefit from the status quo. ${ }^{62}$ Former Vice-President of Fiji, Ratu Joni Madraiwiwi, has observed:

In the Asia-Pacific region there is some resentment about the concept of human rights...Interestingly it is not the downtrodden, the oppressed or the marginalised who make the criticism. It is those of us who are part of established power structures that query the applicability of these rights. ${ }^{63}$

Pacific women, particularly poor rural women, complain about their inability to participate in political decisions and about increasing levels of male violence. ${ }^{64}$ The drafters of a Pacific Charter of Human Rights would need to ensure broad and extensive consultation in determining which customs and human rights should be included in such a document, including comprehensive consultation of women. The key challenge is creating a Pacific Charter of Human Rights that incorporates women's rights while remaining sensitive to Pacific customs and culture.

\footnotetext{
58 Fiji Women's Rights Movement and the Crisis Centre, Report of the Commission of Inquiry on the Courts (1984) 172 in Jennifer Corrin Care, Conflict between customary law and human rights in the South Pacific (1999) $4<$ www.vanuatu.usp.ac.fj/sol-adobe_documents/usp\%20only/pacfic\%20law/corrin> at 20 August 2009.

59 Jolly, above n 40, 135.

60 Fischer, above n 41, 276.

61 New Zealand Law Commission, above n 1, 84.

62 Ibid.

63 Ratu Joni Madraiwiwi, 'Rights and Rites: A Discourse', New Zealand Law Commission Custom and Human Rights Workshop', (Nadi, Fiji, 2008).

64 Jolly, above n 40, 136.
} 


\section{The Current Status of Human Rights in the Pacific}

Pacific nations have a low level of engagement in the international human rights treaty system. ${ }^{65}$ Even where treaties have been ratified, most Pacific nations have failed to meet the reporting requirements of the treaties. ${ }^{66}$ While the Law Association for Asia and the Pacific (LAWASIA) contends that Pacific countries have relatively good human rights records, it concedes that problems still exist in some areas. ${ }^{67}$ These include the status of women, the rights of indigenous peoples and the rights of minorities. ${ }^{68}$ Conversely, Dejo Olowu contends that there is not a 'vibrant culture of human rights protection in the Pacific' ${ }^{69}$ Olowu argues that the Pacific should not be insulated from international human rights protections, and should proceed to ratify all international human rights treaties. $^{70}$

There are many explanations for the perceived indifference of Pacific nations towards international human rights treaties. The primary reason given for low levels of ratification is that many human rights norms are already constitutionally entrenched. ${ }^{71}$ The lack of economic, technical, human and institutional capacity to fulfil the commitments of international treaties is also seen as a significant reason for low levels of ratification and reporting. ${ }^{72}$ Finally, international human rights treaties are perceived as a form of neo-colonialism, whereby former colonial powers and other Western nations force Pacific nations to comply with instruments that have been principally designed by the West. ${ }^{73}$ This last point highlights the importance of designing a charter that reflects the customs and culture of the Pacific, so that the people of the Pacific have a sense of ownership of towards the charter and are not reluctant to implement its provisions.

All Pacific constitutions contain clauses that protect human rights, with the exception of Niue. ${ }^{74}$ Accordingly, many human rights norms are already encapsulated in Pacific law. Most Pacific constitutions also recognise customary

\footnotetext{
65 New Zealand Law Commission, above n 1, 68.

66 Ibid.

67 Law Association for Asia and the Pacific, 'Report on a proposed Pacific Charter of Human Rights prepared under the auspices of LAWASIA, May 1989' in Victoria University of Wellington (ed), Essays and Documents on Human Rights in the Pacific (1992) 99, 101.

68 Ibid.

69 Olowu, above n 24, 164

70 Ibid 163

71 Thaman, above n 14, 2.

72 A. H. Angelo, 'Lo Bilong Yumi Yet' in Victoria University of Wellington (ed), Essays and Documents on Human Rights in the Pacific (1992) 33, 40.

73 Ibid 39-40.

74 A. H. Angelo, 'The Niue Constitution' (2009) 15 Revue Juridique Polynesienne 157, 177.
} 
law. ${ }^{75}$ However, the recognition of custom is often limited by Pacific constitutions to the extent that it conforms with human rights or the protection of justice. ${ }^{76}$ For example section 100(3) of the Constitution of Fiji 1997 provides that custom will apply unless 'inconsistent with a provision of this constitution or a statute, or repugnant to the general principles of humanity'. Furthermore, there is evidence that Pacific courts and legislatures are adjusting the law so that discriminatory customary practices are made illegal. ${ }^{77}$ For example, the decision in 1994 of Noel $v$ Toto in Vanuatu outlawed any discriminatory customs. ${ }^{78}$ These examples suggest that national courts and legislatures are favouring human rights over customary law when engaging in law reform and dispute resolution.

The current system has not reconciled custom and human rights to ensure that both are consistently protected. Epeli Hau'ofa characterises life in the Pacific as occurring at two different levels, the national level of government occurring in capital cities, and that of the ordinary people who 'tend to plan and make decisions about their lives independently' ${ }^{79}$ Courts at the national level (which are often comprised of expatriate judges) are reluctant to use custom in their decisions because judges are unfamiliar with Pacific customs, and find it difficult to apply unwritten law. ${ }^{80}$ Therefore human rights are given more attention by the judiciary and customary law is often excluded from consideration. However, the majority of disputes in Pacific nations do not reach the national level of Pacific legal systems and are instead presided over by chiefly authorities and governed by customary law. ${ }^{81}$ Constitutional protections and human rights are not applied in traditional dispute resolution. ${ }^{82}$ A fundamental question in creating a Pacific Charter of Human Rights is how a regional charter could be effective in addressing this inconsistency in the application of human rights and custom, and whether it would impact on traditional dispute resolution where human rights are most likely to be infringed.

It has been suggested by the New Zealand Law Commission that rather than formulating a Pacific Charter of Human Rights, resources and time would be better spent on attempting to harmonise existing human rights and custom provisions in Pacific constitutions. ${ }^{83}$ Pacific constitutions do not currently recognise collective rights or duties which are integral to the Pacific culture,

\footnotetext{
75 Caren Wickliffe, 'Culture Rights, Culture and Human Rights Education' in Margaret Wilson and Paul Hunt (eds), Culture, Rights and Cultural Rights: Perspectives from the South Pacific (2000) 129, 129.

76 Corrin Care, above n 29, 7.

77 Brown, above $\mathrm{n} 36,4$.

78 Noel $v$ Toto[1995] VUSC 3.

79 Epeli Hau' ofa, 'Our Sea of Islands' (1994) 6(1) The Contemporary Pacific 148, 148.

80 Zorn, above n 7, 97.

81 ibid, 130.

82 Ibid.

83 New Zealand Law Commission, above n 1, 69.
} 
and this is one area that could be addressed. ${ }^{84}$ It is contended that Pacific constitutions are more effective and enforceable and are perceived as locally owned. ${ }^{85}$ Indeed the question of the best means of addressing human rights in the Pacific is pertinent, and the creation of a Pacific Charter of Human Rights is only one of many possible solutions.

The Law Association for Asia and the Pacific (LAWASIA) prepared a Draft Pacific Charter in 1989, which is adapted to the Pacific context and encompasses cultural rights, group rights and duties. ${ }^{86}$ It was hoped that governments of the Pacific would subsequently implement a mechanism based on the document prepared by LAWASIA. ${ }^{87}$ However, Pacific governments are yet to actively or comprehensively engage in the creation of a Pacific Charter of Human Rights. ${ }^{88}$ This may be attributable to the criticism of the draft charter by academics such as Thaman as 'still very much a European document'. ${ }^{89}$ LAWASIA are currently revising the 1989 Draft Pacific Charter, and are advocating for Pacific governments to agree to a basic set of human rights principles that can be applied in the Pacific context. ${ }^{90}$ However, the reluctance that has been demonstrated towards the LAWASIA draft charter begs the question of whether there is sufficient enthusiasm in the Pacific for a regional charter.

\section{Other Challenges in Constructing a Charter}

\section{Minority Rights}

Any attempt to formulate a Pacific Charter of Human Rights that includes custom must consider the rights of minority and migrant communities living in the Pacific. While some Pacific countries only have small minority and migrant populations, non-indigenous people comprise more than a quarter of the populations of Fiji, Nauru and Palau. ${ }^{91}$ A document that incorporates the customs and collective practices of indigenous Pacific peoples could potentially result in marginalisation of minorities and migrant communities and restrict these groups from practicing their own culture and customs. ${ }^{92}$

\footnotetext{
84 Zealand Law Commission, above n 1,69

85 Ibid.

86 Law Association for Asia and the Pacific, above n 67, 107.

87 Ibid 99.

88 New Zealand Law Commission, above n 1, 236.

89 Thaman, above n 14, 3.

90 Law Association for Asia and the Pacific, Profile of LAWASIA (2010) <http://lawasia.asn.au/profile-oflawasia.htm> at 26 October 2010.

91 New Zealand Law Commission, above n 1, 84.

92 Ibid.
} 
The Fijian experience illustrates the complexities inherent in attempting to balance the rights of migrant communities while safeguarding Pacific custom and practices. Fiji has a large Indian population who were originally recruited for plantation work in Fiji during the colonial era. ${ }^{93}$ In the 2007 Fiji Census, out of a population of 837,271 only 475,739 people identified as Indigenous Fijian, and 313,798 identified as Indian Fijian. ${ }^{94}$ The 1990 Constitution of Fiji effectively precluded Indian Fijians from possessing political power and cultural autonomy. ${ }^{95}$ This was justified as uplifting the position of the indigenous community. ${ }^{96}$ However, the constitution was altered in 1997 to reaffirm 'recognition of the human rights and fundamental freedoms of all individuals and groups' and recognise Fiji's multicultural society. ${ }^{97}$ Former Minister for Education, Taufa Vakatale is sceptical of the policy of multiculturalism, which he contends is contributing to the diminishing of Fijian culture. ${ }^{98}$ He contends 'equality in principle becomes discrimination in practice' ${ }^{99}$ Indeed the situation in Fiji illustrates the difficulties of simultaneously protecting the rights of minority groups and Pacific culture, and the reluctance of ministers such as Vakatale to adopt Western liberal values over practices that protect culture and custom.

\section{Codifying Custom}

Pacific customs are incapable of being strictly identified because of their changing and dynamic nature. ${ }^{100}$ Accordingly, codifying Pacific customs would present a challenge for the drafters of a Pacific Charter of Human Rights. Zorn contends that custom is changing at an accelerated rate due to technological, economic and political changes in the Pacific. ${ }^{101}$ Once customary norms are fixed in law they become frozen, and incapable of reflecting the changing nature of custom. ${ }^{102}$

Another challenge to codifying custom in a Pacific Charter of Human Rights is variance in customs between states and within states. ${ }^{103}$ As Zorn states, Pacific

\footnotetext{
93 Brij V. Lal, 'The passage out' in K. R. Howe, Robert C. Kiste and Brij V. Lal (eds), Tides of History: the Pacific Islands in the twentieth century (1994) 435, 448.

94 Fiji Islands Bureau of Statistics, Population Censuses and Surveys (2010) <http://www.statsfiji.gov.fj/ cens\&surveys/cens\&surveystats_index.htm> at 26 October 2010.

95 Amnesty International, Fiji: new era for human rights with new constitution (1998) < http://asiapacific. amnesty.org/library/Index/ENGASA180011998?open\&of=ENG-FJI > at 26 October 2010.

96 Jon Fraenkel, 'The Fiji coup of December 2006: who, what, where and why?' in Jon Fraenkel and Stewart Firth (eds), From Election to Coup in Fiji; The 2006 Campaign \& its Aftermath 420, 422.

97 Constitution (Amendment) Act 1997(Fiji) preamble.

98 Taufa Vakatale, 'Multiculturalism vs. Indigenous Cultural Rights' in Margaret Wilson and Paul Hunt (eds), Culture, Rights and Cultural Rights: Perspectives from the South Pacific (2000) 70, 74.

99 Ibid.

100 New Zealand Law Commission, above n 1, 46.

101 Zorn, above n 7, 96

102 New Zealand Law Commission, above n 1, 43.

103 Zorn, above n 7, 96.
} 
societies were historically heterogeneous: '[e]ach of the indigenous societies of the Pacific had its own customs. Each of the small village societies of the precolonial Pacific was an independent mono-cultural entity' ${ }^{104}$ In order to design an accurate charter, the drafters would have to undertake an inventory of customs applicable to all Pacific nations. Moreover, Pacific governments would need to agree on values, customs and practices common to the region. ${ }^{105}$ Even then, customs could change and consequently render the charter inaccurate.

\section{Conclusion}

Custom is changing and dynamic, and accordingly may be capable of adapting to conform with human rights norms. Human rights thinking must also take into account the perspectives, customs and practices of Pacific peoples. Integral to this process is to create an inventory of Pacific customs, values and practices that are common to and reflective of the entire region and a core of basic human rights common to all cultures in the Pacific. ${ }^{106}$ This would provide the foundations of a viable charter that would harmonise custom and human rights, and would thus be representative of Pacific peoples. However there are still some areas such as women's rights, where custom and human rights are currently in direct conflict. The question is whether a Pacific Charter of Human Rights could resolve this inconsistency and whether a charter would be effective in influencing traditional conflict resolution occurring at a grassroots level, where human rights are most likely to be infringed.

\section{Bibliography}

\section{Articles/Books/Reports}

Amnesty International, Fiji: new era for human rights with new constitution (1998) < http://asiapacific.amnesty.org/library/Index/ ENGASA180011998?open\&of=ENG-FJI $>$ at 26 October 2010

Amnesty International, Pacific Leaders must address high rates of violence against women (2009) < http://www.amnesty.org.au/news/comments/21494> at 26 October 2010

104 Zorn, above n 7, 96.

105 New Zealand Law Commission, above n 1, 283.

106 Corrin Care, above n 29, 16. 
Angelo, A.H., 'Lo Bilong Yumi Yet' in Victoria University of Wellington (ed), Essays and Documents on Human Rights in the Pacific (1992) 33

Angelo, A.H., 'The Niue Constitution' (2009) 15 Revue Juridique Polynesienne 157

Brown, Kenneth, 'Customary Law in the Pacific: An Endangered Species' (1999) 3 Journal of South Pacific Law 1

Butler, Petra, A Human Rights Charter for the Pacific (2005) Human Rights Research: Victoria Human Rights Programme $2<$ http://www.victoria.ac.nz/ nzcpl/HRRJ/vol3/Butler.pdf $>$ at 26 October 2010

Corrin Care, Jennifer, Conflict between customary law and human rights in the South Pacific (1999) 4 <www.vanuatu.usp.ac.fj/sol-adobe_documents/ usp \%20only/pacfic\%20law/corrin> at 20 August 2009

Engle Merry, Sally, 'Changing Rights, Changing Culture' in Jane K. Cowan, Marie-Benedicte Dembour and Richard A. Wilson (eds), Culture and Rights: Anthropological Perspectives (2001) 31

Engle Merry, Sally, Human Rights and Gender Violence (2006) 2

Fiji Islands Bureau of Statistics, Population Censuses and Surveys (2010) <http:// www.statsfiji.gov.fj/cens\&surveys/cens\&surveystats_index.htm $>$ at 26 October 2010

Fiji Women's Rights Movement and the Crisis Centre, Report of the Commission of Inquiry on the Courts (1984) 172 in Jennifer Corrin Care, Conflict between customary law and human rights in the South Pacific (1999) $4<$ www.vanuatu. usp.ac.fj/sol-adobe_documents/usp\%20only/pacfic\%20law/corrin $>$ at 20 August 2009

Fischer, Steven Roger, A History of the Pacific Islands (2002)

Follesdal, Andreas, Human Rights and Relativism (2003) <http://www.etikk. no/globaljustice/papers/GJ2003_Follesdal_Human_Rights_and_Relativism. doc $>$ at 26 October 2010

Fraenkel, Jon, 'The Fiji coup of December 2006: who, what, where and why?' in Jon Fraenkel and Stewart Firth (eds), From Election to Coup in Fiji; The 2006 Campaign \& its Aftermath 420

Hau'ofa, Epeli, 'Our Sea of Islands' (1994) 6(1) The Contemporary Pacific 148

Higgins, Rosalyn, Problems and Process: International Law and How We Use It (1994) 
Hunt, Paul, 'Reflections on International Human Rights Law and Cultural Rights' in Margaret Wilson and Paul Hunt (eds), Culture, Rights and Cultural Rights: Perspectives from the South Pacific (2000) 25

Jolly, Margaret, 'Women ikat raet long human raet o no?: women's rights, human rights, and domestic violence in Vanuatu' in Anne-Marie Hilsdon et al (eds), Human Rights and Gender Politics: Asia-Pacific perspectives (2000) 124

Kanongata'a, Keiti Ann, 'Pacific Women and Theology' (1995) 13 Pacific Journal of Theology 17

Lal, Brij V., 'The passage out' in K. R. Howe, Robert C. Kiste and Brij V. Lal (eds), Tides of History: the Pacific Islands in the twentieth century (1994) 435

Law Association for Asia and the Pacific, Profile of LAWASIA (2010) < http:// lawasia.asn.au/profile-of-lawasia.htm $>$ at 26 October 2010

Law Association for Asia and the Pacific, 'Report on a proposed Pacific Charter of Human Rights prepared under the auspices of LAWASIA, May 1989' in Victoria University of Wellington (ed), Essays and Documents on Human Rights in the Pacific (1992) 99

Macintyre, Martha, 'Hear us, women of Papua New Guinea!: Melanesian women and human rights' in Anne-Marie Hilsdon et al (eds), Human Rights and Gender Politics: Asia-Pacific perspectives (2000) 147

Madraiwiwi, Ratu Joni, 'Rights and Rites: A Discourse', New Zealand Law Commission Custom and Human Rights Workshop', (Nadi, Fiji, 2008)

New Zealand Law Commission, Converging Currents: Custom and Human Rights in the Pacific (2006)

Olowu, Dejo, 'The United Nations Human Rights Treaty System and the Challenges of Commitment and Compliance in the South Pacific' (2006) 7 Melbourne Journal of International Law 155

Powles, Guy, 'Duties of individuals: some implications for the Pacific of including "duties" in "human rights" documents' in Victoria University of Wellington (ed), Essays and Documents on Human Rights in the Pacific (1992) 49

Steiner, Henry J., Phillip Alston and Ryan Goodman, International Human Rights in Context: Law, Politics, Morals (3rd ed, 2008)

Thaman, Konai Helu, 'Cultural Rights: A personal perspective' in Margaret Wilson and Paul Hunt (eds), Culture, Rights and Cultural Rights: Perspectives from the South Pacific (2000) 1 
Taufa Vakatale, Taufa, 'Multiculturalism vs. Indigenous Cultural Rights' in Margaret Wilson and Paul Hunt (eds), Culture, Rights and Cultural Rights: Perspectives from the South Pacific (2000) 70

Wickliffe, Caren, 'Culture Rights, Culture and Human Rights Education' in Margaret Wilson and Paul Hunt (eds), Culture, Rights and Cultural Rights: Perspectives from the South Pacific (2000) 129

Zorn, Jean G., 'Custom then and now: the changing Melanesian family' in Anita Jowitt and Tess Newton Cain (eds), Passage of Change: Law Society and Governance in the Pacific (2003) 95

Zorn, Jean G., Women,Custom and International Law in the Pacific (Occasional Paper 5, University of the South Pacific, Port Vila 2000)

\section{Case Law}

Noel $v$ Toto [1995] VUSC 3

\section{Legislation}

Constitution (Amendment) Act 1997 (Fiji)

\section{International Law}

African Charter on Human and Peoples' Rights, opened for signature 27 June 1981, 1520 UNTS 217 (entered into force 21 October 1986)

Convention on the Elimination of All Forms of Discrimination Against Women, opened for signature 18 December 1979, 1249 UNTS 13 (entered into force 3 September 1981)

International Covenant on Civil and Political Rights, opened for signature 16 December 1966, 999 UNTS 171 (entered into force 23 March 1976)

International Covenant on Economic, Social and Cultural Rights, opened for signature 16 December 1966, 993 UNTS 3 (entered into force 3 January 1976)

United Nations, The Universal Declaration of Human Rights, (1948) <http:// www.un.org/en/documents/udhr/index.shtml $>$ at 26 October 2010 